\title{
Corporate Social Responsibility in Educational Programme among Malaysian Primary Schools: Perspectives from Corporate Companies in Malaysia
}

\author{
ATHIRAH AZHAR ${ }^{1}$, AZLINDA AZMAN $^{2}$ \\ ${ }^{1}$ Faculty of Social Sciences and Humanities, UNIVERSITI MALAYSIA SARAWAK. Email: aathirah@unimas.my \\ ${ }^{2}$ School of Social Sciences, UNIVERSITI SAINS MALAYSIA.
}

\begin{abstract}
This study was conducted to acquire the corporate companies' perspectives on educational programmes under their Corporate Social Responsibility (CSR) initiatives. It was found out that very little research on educational programmes conducted under CSR initiatives. The aims of the study; therefore, to identify the goals of CSR educational programmes initiatives in rural primary school, to highlight the impact of CSR educational programmes initiatives to the pupils and rural primary school from corporate perspectives; and; to highlight corporate companies' suggestions in reaching out to more rural schools. Qualitative research method was chose by interviewing five corporate companies which were purposively selected. This exploratory study was analysed based on themes that emerged such as educational programmes goals, impact on pupils, impact on rural primary schools and concern from corporate companies. Findings revealed that the main educational programmes goal is to improve the educational achievement in school. This is by having motivational and team building programmes, educational support programmes, environmental programmes for pupils; training and development for teachers; and motivational talks for parents. Corporate companies stated that participated pupils in CSR educational programmes, have made teachers, school and their parents proud. It was due to improvements among participated pupils by achieving good and better grades in academics and gained selfconfidence. Thus, schools were contented that the school ranking has improved. Corporate companies did express their concern on the sustainability of the programme once the educational programme ended. This study concluded that educational programmes under CSR initiatives have given good impact to pupils and schools but, there was no presence of educational programme sustainability in a long-term towards both pupils and school. (268 words)
\end{abstract}

Keywords: Corporate Social Responsibility, Educational Programme, Education, Primary School, Social Work.

Classification JEL: M14, L21

Recibido: 2 de Diciembre de 2020

Aceptado: 14 de Diciembre de 2020 


\section{Introduction}

Corporate Social Responsibility (CSR) is a concept that has endured, continues to grow and giving good impact to the community. Europe, Asia, Australia, Africa, South America and many developing countries are increasingly embracing the idea in one form or another (Carroll, 2016). Carroll (2016) also added that CSR has been an important and progressing topic since 1950s. In this new era, CSR should be upgraded to CSR2.0. The macro shifts for newly CSR 2.0 were supposed to be from philanthropic to collaborative, risk-based to reward-based, image driven to performance driven, specialised to integrated, standardised to diversified, marginal to scalable and western to global (Visser, 2011). CSR 2.0 or transformative CSR focuses its activities on identifying and tackling the root cause of present unsustainability and irresponsibility, which are through business model, revolutionising their processes, products, services and lobbying; for progressive national and international policies (Visser, 2014, p. 16). Companies from local or multinational; and from any types of industries; have been involving in CSR initiatives since more than a decade. Mass CSR initiatives have been implemented to all community levels. In Malaysia, this includes for health (health-care programmes and disaster relief), education (internship, schooling aid, scholarship and equipment / tools for education) and; living standards (equipment / tools such as sewing machines and water pumps; house re-construction, alms and business loan assistance) (Ismail et al., 2014). Besides, CSR has also reached out to schools by conducting CSR educational programmes in schools.

Not many research is keen to look at programme evaluation. This is crucial to see the effectiveness of the programme and how it can be improved. It is argued that, Royse, Thyer, Padgett, and Logan (2006) stated that although many authorities have considered that programme evaluation would be the most valuable type of research contribution, such study seems to be rarely undertaken and published (p. 2). Undeniably, CSR educational programmes evaluation has been conducted by the corporate companies themselves but it is also essential to look from the academic's point of view. Gautier and Pache (2013) stated scholarly interest in corporate philanthropy, has seen that more to be explored in a context where the respective roles of business, governments and civil societies experiencing fundamental changes such as pointing to who the corporates are, what may motivate them, how they may behave and the impact.

In Malaysia, the most popular themes in the CSR practices in community is education which the highest was giving scholarship followed by internship in companies, schooling and equipment for education (Ismail, Alias, \& Rasdi, 2015). Ismail et al. (2014) stated that no research was conducted on the educational programme. Though the educational programmes have a given a huge impact on school, still it is crucial to know from the corporate's perspectives the impacts of educational programme towards the participants. According to Ismail et al. (2014), CSR has improved school physical infrastructure, facilities and teachers become more innovative through trainings that have been provided. Most of the studies in Malaysia are less on awareness and perception towards CSR. (Mohd Nasir, Abdul Halim, Mohd Sallem, Jasni, and Aziz, 2015)

The researcher then came out with three research questions to address the following research questions specifically from the perspective of corporate companies which are as follows;

i. what are the goals of CSR educational programmes in rural primary school?

ii. what are the impacts of CSR educational programmes under CSR initiatives to the pupils in rural primary school from corporate perspectives?

iii. what are corporate suggestions in reaching out to more rural schools?

This study is significant as CSR educational programmes should be a long-term programme until the community or an individual are developed and are able to help themselves. This subsequently to promote collaboration among private and public partnership. Moreover, this study was to enhance the importance of the education especially among the children in the rural areas. If the CSR educational programmes could help a part of children's education, then it would be more meaningful 
if more corporate companies could involve in the educational programmes in schools around Malaysia.

\section{Literature Review}

\subsection{CSR in Malaysia}

In a study about CSR in Malaysia, Mohamed Zain and Mohammad (2007) mentioned that the most popular theme was human resource and the most popular sub-themes were education, participation in sports, culture and philanthropy. Moreover, a research by Ismail et al. (2015) stated that the education-related initiative being the most dominant for CSR types of programmes. These include training and informal education in health-related matters, such as breast cancer awareness and rehabilitation of flood victims in the community (Ismail et al., 2015). Abdulrazak and Ahmad (2014) emphasised on shared value for CSR in Malaysia which said it should be made between firm and the society. The emphasise could be on sharing corporate's perceptions on their CSR initiatives which subsequently would attract more corporate companies to get involved. More can be done through CSR creatively without looking at the cost and time as an issue. Earlier, Khazanah Nasional Berhad has produced The Silver Book containing CSR guidelines to assist corporate companies in their CSR initiatives (Ahmad \& Saad, 2013).

Mohamed Zain and Mohammad (2007) has proven a success in Malaysia local giant companies such as Guthrie, Sime Darby, Petronas, IJM and YTL that have shown great improvements in their CSR disclosure. Moreover, they are exporting the Malaysian cultures and values to their subsidiaries abroad (Mohamed Zain \& Mohammad, 2007). Mutuc and Lee (2019) recent research on CSR from Asian context stated that CSR is no longer a concept in Asia because of fair distribution of wealth, environmental protection, community relations, along with the improvement of economic values.

In Malaysia, CSR practices were still at the corporate philanthropic stage (Azlan Amran et al., 2013). This means that the programme or practice are one-off there are lack of sustainability in CSR. Earlier, Azlan Amran et al., (2013) stated that CSR concept was still new for many Malaysians that needed a greater understanding from the local communities, but if it was properly done, it would benefit community in a long run. Recent research on CSR in Malaysia by Hizam, Othman, Amin, Zainudin, and Fattah (2019) stated that companies in Malaysia are starting to realize the importance of social responsibility as a way of communication with stakeholders and with the community in the performance of their businesses. Moreover, the initiative by Malaysian government to provide government tender to company with high index of CSR is likely to increase company interest toward adoption of CSR practice beyond the requirement (Awalluddin et al., 2019).

\subsection{CSR Involvement in Social Justice in Education (SJE)}

Freire's (2000) concept said that education should be looked at the people who are oppressed and the oppressor should also put an effort and play their role to assist the oppressed to be successful. In this context of SJE, surrounding communities and working people (both private and government agencies) should not just come out with education policy but also involve in nurturing and educating children in school. Freire (2000) also said that education can make or remake the person. It is also part of the CSR initiatives responsibility to educate on the importance of education to children and spread awareness to parents in the rural areas or else this would make the students absent and drop out from school. Some of the parents would rather let their children get the source of revenue for their family. A decade ago, Eshach (2007) also emphasised that teachers are doing important and crucial work, invest a lot of effort which is why building bridges and out-of-school learning is crucial.

As suggested by Hytten and Bettez (2011), SJE helps to transform oppression and expend educational opportunities for marginalised groups. SJE also acts as a tool for examining how oppression operates in the social system and in the individuals personals lives that comes from a diverse communities (Bell, 2016, p. 3). Clearly, the main goal for SJE is to enable individuals to develop 
their own critical analytical tools (Bell, 2016, p. 3). Cooperation and collaboration with corporate companies and schools are needed to nurture creative thinking in children. In this post-modern era, learning for children in school should come with various styles rather than one-way communication by teachers. It is injustice that children are not able to relish non-formal education such as fun in learning in educational programmes. Pretsch, Ehrhardt, Engl, Risch, Roth, Schumacher, \& Schmitt (2016) in their longitudinal study in injustice in students' emotions and well-being which includes arbitrary privilege, unfair allocations of time and attention. It is also injustice where children from underserved areas, with no exposure and not being heard by others such as corporate companies and professionals. Plus, Aguilar (2018) stated that it is unfair and ineffective to expect teachers to personalise the experiences of each of the students without other individuals or agency 6iujzassisting the teachers.

\subsection{Programme Theory}

This research adopts the 'programme theory' as it has been used by evaluators to develop the best outcome to a programme (Rogers et al., 2000); and will be helpful at all stages of evaluation including planning, implementing, and impact assessing (Reynolds, 1998). Programme theory describes about programme content; predicts the end result of the programme; specifies what needs to be done base on aim of the programme and outcomes of the programmes by domain (Reynolds, 1998: Sidani, 1999). Moreover, Sidani (1999) specified that this theory consisted (1) the nature, and duration of the activities that should be performed to achieve the programme outcomes, (2) the resources needed for the programme, and (3) the procedures to be followed in the programme.

The relevance of the theory to this study is that it evaluates CSR educational programmes. The evaluation is from corporate companies perspectives. It is wide-ranging to conceptualise and evaluate the programme that covers all the factors. Furthermore, Rogers et al., (2000) added that it is impossible to design an evaluation that covers all the identified factors in programme theory. In this research findings, it describes CSR educational programme contents and goal, impact to participated pupils and rural primary schools, and what needs to be done to reach out to more rural primary schools. From the findings, it is hope to attract more corporate companies collaborate with schools in rural areas to conduct CSR educational programme.

\section{Methods}

Qualitative researchers can move beyond common practices to include lived experience in the creation and interpretation of knowledge (Devotta, Woodhall-Melnik, Pedersen, Wendaferew, Dowbor, Guilcher, Hamilton-Wright, Ferentzy, Hwang, \& Matheson, 2016). This is why qualitative study is best to describe as the experience and interpretation of knowledge were from corporate companies on CSR educational programmes towards pupils and rural primary school. A case study of adopt-a-school (AASC) programme was chose as it was conducted in most of the rural primary schools throughout Malaysia. AASC programme involved corporate companies and government-link companies that work together to adopt school in the rural areas or in underserved areas. The school adoption period is three years. Once the adoption period ends, the company will then leave to adopt other school. This has been a practice for many years so that more schools could benefits educational programmes by the corporate companies. AASC programme is part of the CSR initiatives. AASC programmes involved other stakeholders such as federal and state government. Cooperation and collaboration from many stakeholders in Malaysia has make AASC still on-going after so many years.

The CSR educational programme initiatives is managed by a foundation which has 43 corporate companies as its members. For this research, purposive sampling was used. The criteria given to the foundation to choose the company to be interviewed is, the company that has completed CSR educational programmes in the schools in northern region states of Malaysia. With the foundation assistance, five representatives from five corporate companies have agreed to be interviewed. Appointments were made with all representatives for an interview. Face to face interview were 
conducted to all companies except Company 1 where the interview was conducted over telephone. All five companies are Government Link Companies (GLCs) and their headquarters are situated in the capital city of Malaysia, Kuala Lumpur. Besides, the interviews were held in the main head quarter office for each of the company. Before the interview, all respondents were explained in detail about the objectives of the research. Interviews with each of the respondents took approximately 45 minutes.

Five respondents have participated in this research where their company had involved in CSR initiatives by organising educational programmes in rural primary school throughout Malaysia. Respondents that agreed to be interviewed are from five companies in which their positions are the Manager of Corporate Responsibility from communication services provider company, Corporate Communication Assistant Manager from financial services company, Executive Corporate Communication from developer company, Manager of Corporate Planning from industrial products and services company; and Manager of CSR from banking and finance services company (refer Table 1).

Table 1 Demographic of Respondents

\begin{tabular}{|c|c|}
\hline Company & Rank \\
\hline $\begin{array}{l}\text { Company } 1 \\
\text { (communication services provider) }\end{array}$ & Manager of Corporate Responsibility \\
\hline $\begin{array}{l}\text { Company } 2 \\
\text { (financial services) }\end{array}$ & $\begin{array}{l}\text { Corporate Communication Assistant } \\
\text { Manager }\end{array}$ \\
\hline $\begin{array}{l}\text { Company } 3 \\
\text { (developer) }\end{array}$ & Executive Corporate Communication \\
\hline $\begin{array}{l}\text { Company } 4 \\
\text { (industrial products and services) }\end{array}$ & Manager Corporate Planning \\
\hline $\begin{array}{l}\text { Company } 5 \\
\text { (banking and finance services) }\end{array}$ & Manager of CSR \\
\hline
\end{tabular}

Techniques of data collection were semi-structured interviews. The research follows four different steps including i) familiarisation ii) transcription iii) data organisation iv) coding and identifying theme. In familiarisation process, the researcher listened to recordings from the interview which take approximately 45 minutes. The recordings were from four interviews which were conducted face to face while one interview was over the telephone. Then, the transcription process involved the researcher to listen to all recordings and transcribe. It is also to understand, establish, and assume a set of principles and practices, in an attempt to harmonize transcripts (Azevedo, Carvalho, Costa, Mesquita, Soares, Teixeira, \& Maia, 2017). Each of the data were given a name and was safely kept with the researcher to ensure privacy. The results were divided into four themes which are CSR educational programme goal from corporate companies' perspectives, impacts of CSR educational programmes from corporate companies' perspectives and concern from corporate companies.

For ethical considerations, the researcher wrote an email to make clear on the research that the researcher was conducting and requested the corporate companies to be interviewed. Then, the researcher has visited each of the companies in their headquarter offices in Kuala Lumpur to interview them and only one was interviewed via telephone call. Respondents were told that interviews will be recorded. Three out of five companies requested that the company's name not to be mentioned or stated. To be fair, the researcher did not disclose any names that have been interviewed. With that, 
interviewed corporate companies were labelled as Company 1 , Company 2, Company 3, Company 4 and Company 5.

\section{Results}

In results section, answers will be provided on the corporate companies' perceptions on CSR educational programmes towards participated pupils and rural primary schools. The results were divided into four themes which are CSR educational programme goal from corporate companies' perspectives, impacts of CSR educational programmes from corporate companies' perspectives and concern from corporate companies.

\subsection{CSR Educational Programme Goal from Corporate Companies' Perspectives}

All interviewed companies stated that they have achieved CSR educational programmes goals that have been organised under their companies' CSR initiatives. All companies have the same goal which to reach out student in the rural as well as to assist rural school. Pupils were able to gain new knowledge and experience. Besides, Company 2 was contented that pupils are able to speak in English as well as able to build their self-confidence. English related programmes were organised in school in collaboration with public university. Some of the university student came to school to conduct English programmes with the pupils. What companies were proud of was when participating pupils in educational programme achieved good results in their examination as well as in English subject. Company 2 stated that it was indeed a big achievement for the company in CSR educational programme to see the progress in the rural school.

Company 1 stated that educational programmes are focusing on holistic approach to school and surrounding areas. According to Company 1, the holistic approach includes leadership programme, educational support programme, capability and capacity building; and; reducing vulnerabilities and social issues. As mentioned by Company 1, corporate companies also supporting government for pupil's education in the rural areas.

"Basically, just to support the government agenda in education at the same time we want to give the better learning experience to this student that is located in the rural areas by giving the opportunities to have the same experience like the urban school students so why not"

Other than that, Company 5 clearly stated their CSR goal in educational programmes;

"To help improve the educational achievement of children from low income families across all states in Malaysia, to support motivational programme based on the schools' requirement, to assist the schools educational programme for students and teachers by providing supporting materials for learning and teaching; and; to extend financial aid to underprivileged students (basic requirements-school uniform, books and related fees)"

Some examples of educational programmes that have been conducted in rural primary schools are motivational and team building programme, educational support programme, environmental programme, training and development for teachers; and motivational talks for parents. All companies have been given a guide and examples of programmes by the foundation. Companies were given the flexibility to implement these programmes in schools.

\subsection{Impacts of CSR Educational Programmes from Corporate Companies' Perspectives}

Impacts on Pupils. Company 4 was delighted when CSR educational programmes organised in school has given a great impact to participated pupils which consequently made parents happy. More, parents, teachers and schools expressed their gratitude as their children has made a great achievement in academic performance. Pupils that could not get good grades in their academic results before, get A's. Besides that, pupils that could not read and write well has achieved excellently in their academic results. This has made a great achievement and collaboration for corporate companies and 
school. Pupils has built up their self-confidence as well as could speak in English as stated by Company 2 below.

"Before, student no confident and could not speak English. We call consultant to conduct program then we organised essay writing in English on specific topic. Surprisingly there are student that really shine. Winners we gave computer to school"

Other than that, Company 4 stated that pupils would be able to learn new things that they have never experienced in their school before. Such as playing Lego, making robots from Lego and participated in international robot competition. Pupils were also delighted that they were able to go for study trips in other states. Company 4 stated that school would like to organise all these to their pupils but because of the financial constraint, programmes that can be conducted are very limited.

Every schools have Parents and Teachers Association (PTA) where some fund were collected from parents in assisting schools organising any activities or programmes for their children. Talking about PTA funds, not much can be collected from the parents who are also living in the rural areas. The parents usually do not earn that much as they are working in the agriculture industry such as a farmer that is working in the paddy field or labour at the palm oil plantation. There are also parents working as a factory labour worker.

Impacts on Rural Primary Schools. Company 3 stated that schools too have expressed their gratitude to corporate companies as their school academic performances have progressively improved. Pupils that have difficulties in reading before participated in CSR educational programme are able to read after the programme. Company 5 stated that, if in need, they also get NonGovernmental Organisation (NGO) involved to assist if pupil have learning difficulties. This is a collaborative effort for pupils that involved a corporate company, an NGO and a school.

As stated by Company 1, programmes and training for teachers were also held so that teachers will be able to learn new skills and techniques in teaching. These programmes and trainings were all fully sponsored by a company. According to the schools, after attending the programmes, teachers are more motivated.

Company 3 stated that community in the rural areas were very warm and welcoming everytime the respondent and team from company come to visit the school. Moreover, parents were very cooperative and committed that they sent their children every time CSR educational programmes are conducted in school. Company 3 stated that they will either bring experts to school or allocate some budget for allowance to teachers to conduct extra additional classes after school or weekend. Moreover, if the CSR educational programmes were conducted during the weekend, the villagers' community will come to school and prepare food for everyone in school. For food preparation, the budget was also allocated by the corporate company.

Other than that, a Company 1 stated looking at the poor condition of the school, they also upgraded facilities in schools such as they created mini computer lab, bought new books for the school library, bought good books for principal and teachers; and bought scientific calculators. Company 5 mentioned that they also helped school in terms of early school preparation such as providing school uniforms and stationaries for the pupils. Not just that, school was also provided stationaries for pupils that will sit for final exams. Company 5 mentioned that they also helped school in terms of early school preparation such as providing school uniforms and stationaries for the pupils. Not just that, school was also provided stationaries for pupils that will sit for final exams. Company 5 also stated that they would not allocate the budget in terms of school infrastructure but emphasised on the implementation of educational programmes as well as to improve educational achievement in rural school.

\subsection{Concerns from Corporate Companies}

Company 5 stated that educational programmes in school is one good initiatives under CSR. Rural schools do need extra fund to organise educational programmes for pupils and teachers. This would 
help to ease principal and teacher's burden in getting extra funds to organise programmes in school or to hold an examination for pupils.

Company 5 stated that they will be reaching out to more schools in the coming years. Besides, corporate companies are also working with other corporate companies in Malaysia and they work together to give assistance in rural schools. Company 3 said that for the schools in Selangor, Penang and Johore, any companies could come and approach as they are near the city. It was suggested that to reach out to the schools that is located far out from the city. It is the responsibility of the company to reach out to rural schools. Company 5 suggested that to discuss with schools on the best needs of the schools, school's culture and community surround's culture. This is to curb from one man show which school does not benefit from the educational programmes conducted. Moreover, corporate should also empower schools and it would be best if CSR educational programme impacted school in a long term. As suggested by a Company 3 below;

"For this programme to sustain is to appoint one coordinator among the teachers from the school. Have to work with teachers and village leader."

\section{Discussion}

All the interviewed respondents stated that their companies' goals for each school in the CSR educational programmes have been achieved. Based from the interview, the respondent stated about numerous changes during and after the educational programmes have been conducted in schools. The changes were when pupil and school academic performances have progressively improved during that 3 years of adoption and CSR educational programmes in the school. The achievements for CSR educational programmes were the companies were able to apply holistic approach in CSR educational programmes for pupils, better academic achievement for pupils and schools. Moreover, the companies added that CSR educational programmes have given good opportunities to school, provide knowledge and experience to both pupils and teachers; and; more additional motivational programmes were able to be conducted. All these are in line with Sharpe (2011) that stated the important considerations in programme evaluations are the programme components utilised by the client, the amount of treatment actually received, and the integrity of the services provided

Besides that, pupils have benefitted through new knowledge and experiences, improved their English proficiencies and from no ' $A$ ' grade to ' $A$ ' grade in their academic exams. Consequently, pupils were seen happy with the programme, able to read better, confidence and built up their character. In fact, parents and schools have given positive feedback about the programmes. Certainly, goals for educational programmes have been achieved but only during right after the CSR educational programme ended. That means after the adoption period of three years has come to an end. Once ended, the companies left and schools went back to normal. CSR educational programme should be continue, or on the other hand, it should be a sustainable educational programme especially in the rural areas. This is why it is crucial that CSR educational programmes practice has to be upgraded to another level which is either CSR 2.0 or transformative CSR. As stated by Visser (2014) CSR 2.0 comprised as follows;

\begin{tabular}{ll}
\hline creativity & $\begin{array}{l}\text { CSR innovation from CSR } \\
\text { codes and standards }\end{array}$ \\
\hline scalability & $\begin{array}{l}\text { responsible and } \\
\text { sustainable projects }\end{array}$ \\
\hline responsiveness & $\begin{array}{l}\text { cross-sector partnership } \\
\text { and stakeholder driven } \\
\text { approaches at every level }\end{array}$
\end{tabular}




$\begin{array}{ll}\text { glocality } & \text { think global act local } \\ & \text { circularity: products and } \\ \text { processes to inherently } \\ \text { 'good' rather than 'less bad }\end{array}$

(p. 40)

With a combination of CSR 2.0 and good programme characteristics would attract more corporate companies to contribute in CSR educational programmes in rural schools. Royse et al., (2006) suggested, some of the good programme characteristics could be referred to the result of educational programme, community acceptance, has conceptual or theoretical foundation, systematic efforts, and how customers were treated (p. 9). Assuredly, by looking at a positive side, maintaining the relationship with schools, gave corporate companies a great impact in a long-term.

Loads of positive feedbacks on CSR educational programmes were received from participated schools, teachers and the community surround. This was due to the fact that, schools have gone through a lot of changes during the three years of educational programmes that the academic performance have become extremely better. Thus, a school has become one of the best school in that surrounding area right after the CSR educational programme ended. Moreover, school principal and teachers have more ideas after they have been sent for trainings to keep updated on teaching technique and English language workshop by British Council. This had helped teachers in their teaching process in the classroom. Some of the schools were provided with facilities such as mini computer lab and that have made them very delighted. Pupils from the participating programme were enthusiastic and there were a lot of positive changes in them. Moreover, the companies stated some of the feedbacks from principal in participated school, pupils have changed to a much better attitude such as being more disciplined, motivated and eager to learn.

Parents have given full support by sending their children in all CSR educational programmes conducted in school. They even sent their children for intensive additional classes that was conducted in the evening. Some corporate companies also conducted talks in school for parents and also sponsored religious programme for parents and rural community surrounded in that area. Eshach (2007) added that schools should remain schools; but educators must establish the connection with out-of-school learning, informal or formal with the in-school learning. Activities collaboration with outsiders into the classroom will make stronger interactions between schools and outsiders; as well as parents involvement will give positive affect on the child's motivation, attitudes, and self-image (Eshach, 2007). However, Visser (2014) has stated in his book for local CSR to follow the community cultural tradition (p. 60). This is indeed true as corporate companies' culture would not be accepted by the local community in the rural areas. As such, school-companies collaboration for CSR educational programme should be emphasised but should also consider local community culture and way of life.

Corporate companies added that during three years of CSR educational programmes, every year grade six pupils that sat for Primary School Evaluation Test (PSET) examination, obtained good results and better grades. This was due to a lot of additional classes that have been conducted for them as well as invited the examiners of PSET examination to give talks. Thus, because of good results in PSET, school ranking in some particular states has moved up to a better rank. Moreover, this is due to a collaboration between, corporate companies, school and surround rural community. Corporate companies provide funding and schools are able to conduct extra additional classes for their pupils with teacher's assistance. These collaborations would subsequently help pupils once they are in high school and in higher education. CSR educational programmes have made them well-prepared, broad minded as well as determining their dreams and what to pursue when they are at the higher education level. At the same time this would also prepare the quality of future workforce in Malaysia. Mutuc and Lee (2019) in their findings stated that CSR programs have no significant effect in the short run, but it generates a positive outcome in a firm's future financial performance in the long-run. 
After two or three years of CSR educational programme, corporate companies have to leave to give assistance to other rural school. How would rural school continue to conduct educational programmes for their pupils as they are short of funding? As stated in the findings that pupil's parents do not earn much to make contribution to school to assist in additional educational programmes for pupils. CSR educational programmes in school should be continued and not completely end. CSR educational programmes should not just be a 'responsibility' but it should be 'sustainable' or long-term for all corporate companies in assisting children and education in rural schools.

\section{Conclusion}

CSR educational programmes initiatives have given positive impact to pupils, teachers, rural primary schools and communities in that area. Participated pupils have improved their academic performance and; teachers were able to be sent for more trainings and workshops. CSR educational programme initiatives collaborate with rural primary school to give assistance in terms of academics as well as to assist government to enhance education in rural areas. Corporate companies do emphasise that the focus is on academics in school and not on the schools' infrastructure. This is because the main objective for corporate companies is to improve educational achievement in school where some of the participated schools were provided a mini computer lab and added more new books in the library. Thus, that was why the focus was more on the CSR educational programmes' implementation. When it comes to children's education, CSR initiatives should be in long term so that other children in the rural could also benefits CSR educational programme. As the school is in rural areas, none or very less agencies or companies that school could approach for funding. It should be corporate companies' initiatives to go in the rural and reach out the school. Every year, new pupils enrol in school and it would be a loss for this new generation that would not be able to join the same educational programmes like their seniors. In conclusion, CSR educational programmes initiatives have given good impact to pupils and schools. Educational programme in rural should not just be corporate social responsibility but it should be corporate social sustainability.

\section{Declaration of Ownership}

This report is our original work

\section{Conflict of Interests}

None

\section{Ethical Clearance}

This study was part of the main author doctoral thesis and the research has been approved by University Sains Malaysia (USM).

\section{References}

1. Abdulrazak, S. R., \& Ahmad, F. S. (2014). The Basis for Corporate Social Responsibility in Malaysia. Global Business and Management Research: An International Journal, 6(3), 210-218. http://www.gbmr.ioksp.com/pdf/vol. 6 no. 3/v6n3-4.pdf

2. Aguilar, S. J. (2018). Learning analytics: At the nexus of big data, digital innovation, and social justice in education. TechTrends, 62(1), 37-45. https://doi.org/10.1007/s11528-017-0226-9

3. Ahmad, J., \& Saad, S. (2013). Beyond Theory and Practice: A Malaysian Case Study. In J. Ahmad \& D. Crowther (Eds.), Education and Corporate Social Responsibility: International Perspectives (pp. 17-34). Emerald Group Publishing Limited.

4. Awalluddin, M., Ramlan, I., \& Maznorbali, A. S. (2019). Asessment on level of corporate social responsibility (CSR) among public listed companies (PLCS) in Malaysia: A study from company secretaries. Journal of International Management, Educational and Economics Perspectives, 7(1), 21-30.

5. Azevedo, V., Carvalho, M., Costa, F., Mesquita, S., Soares, J., Teixeira, F., \& Maia, Â. (2017). Interview transcription: Conceptual issues, practical guidelines, and challenges. Revista de 
Enfermagem Referência, 4(14), 159-167. https://doi.org/10.12707/riv17018

6. Azlan Amran, Mustaffa Mohamed Zain, Maliah Sulaiman, Sarker, T., \& Say Keat, O. (2013). Empowering society for better corporate social responsibility: the case of Malaysia. Kajian Malaysia, 31(1), 57-78.

7. Bell, L. A. (2016). Theoretical foundations for social justice education. In M. Adams, L. A. Bell, D. J. Goodman, \& K. Y. Joshi (Eds.), Teaching for Diversity and Social Justice (3rd ed., pp. 3-26). Routledge Taylor \& Francis Group.

8. Carroll, A. B. (2016). Carroll's pyramid of CSR: Taking another look. International Journal of Corporate Social Responsibility, 1(1), 1-8. https://doi.org/10.1186/s40991-016-0004-6

9. Devotta, K., Woodhall-Melnik, J., Pedersen, C., Wendaferew, A., Dowbor, T. P., Guilcher, S. J. T., Hamilton-Wright, S., Ferentzy, P., Hwang, S. W., \& Matheson, F. I. (2016). Enriching qualitative research by engaging peer interviewers: A case study. Qualitative Research, 16(6), 661-680. https://doi.org/10.1177/1468794115626244

10. Eshach, H. (2007). Bridging in-school and out-of-school learning: Formal, non-formal, and informal education. Journal of Science Education and Technology, 16(2), 171-190. https://doi.org/10.1007/s10956-006-9027-1

11.Freire, P. (2000). Pedagogy of the Oppressed (30th ed.). The Continuum International Publishing Group Inc. https://doi.org/10.1021/acssuschemeng.7b02549

12.Gautier, A., \& Pache, A. C. (2013). Research on Corporate Philanthropy: A Review and Assessment. Journal of Business Ethics, 126(3), 343-369. https://doi.org/10.1007/s10551-013-1969-7

13.Hizam, S. M., Othman, Z. I. S. B., Amin, M. M., Zainudin, Z., \& Fattah, M. F. A. (2019). Corporate social responsibility in Malaysia. International Journal of Financial Research, 10(5), 381-386. https://doi.org/10.5430/ijfr.v10n5p381

14.Hytten, K., \& Bettez, S. C. (2011). Understanding education for social justice. Educational Foundations, 25(1-2), 7-24.

http://anti-oppressive-

education.uregina.wikispaces.net/file/view/Understanding+education+for+social+justice.pdf/307 430312/Understanding education for social justice.pdf

15.Ismail, M., Alias, S. N., \& Rasdi, R. M. (2015). Community as stakeholder of the corporate social responsibility programme in Malaysia: Outcomes in community development. Social Responsibility Journal, 11(1), 109-130. https://doi.org/10.1108/SRJ-05-2013-0053

16.Ismail, M., Fauzi, R., \& Johar, A. (2014). School as stakeholder of corporate social responsibility program: Teacher's perspective on outcome in school development. The Asia-Pacific Education Researcher, 23(2), 321-331. https://doi.org/10.1007/s40299-013-0107-8

17. Mohamed Zain, M., \& Mohammad, R. (2007). CSR in Malaysia: The Dawn of a New Beginning. University Publication Centre (UPENA).

18. Mohd Nasir, N. E., Abdul Halim, N. A., Mohd Sallem, N. R., Jasni, N. S., \& Aziz, N. F. (2015). Corporate Social Responsibility: An Overview. Journal of Applied Environmental and Biological Sciences, 4(10S), 82-87. https://doi.org/10.15373/2249555x/june2013/107

19.Mutuc, E. B., \& Lee, J. S. (2019). Corporate social responsibility and market-adjusted stock returns: An asian perspective. Asia-Pacific Social Science Review, 19(3), 88-107.

20.Pretsch, J., Ehrhardt, N., Engl, L., Risch, B., Roth, J., Schumacher, S., \& Schmitt, M. (2016). Injustice in school and students' emotions, well-being, and hehavior: A longitudinal study. Social Justice Research, 29, 119-138. https://doi.org/10.1007/s11211-015-0247-5

21.Reynolds, A. . (1998). Confirmatory Program Evaluation: A Method for Strengthening Causal Inference. American Journal of Evaluation, 19(2), 203-221.

https://doi.org/10.1177/109821409801900204

22.Rogers, P., Petrosino, A., Huebner, T. a, \& Hacsi, T. a. (2000). Program Theory Evaluation : Practice, Promise, and Problems. New Directions for Program Evaluation, 87, 5-14.

https://doi.org/10.1002/ev.1177

23.Royse, D., Thyer, B. A., Padgett, D. K., \& Logan, T. K. (2006). Program Evaluation: An Introduction 
(4th ed.). Thomson Brooks/Cole.

24.Sharpe, G. (2011). A Review of Program Theory and Theory-Based Evaluations. American International Journal of Contemporary Research, 1(3), 1998-2001.

https://doi.org/10.1007/s10257-008-0105-1

25.Sidani, S. (1999). Putting Program Theory into Operation. American Journal of Evaluation, 20(2), 227-238. https://doi.org/10.1177/109821409902000205

26.Visser, W. (2011). The Age of Responsibility: CSR 2.0 and the New DNA of Business. John Wiley \& Sons, Inc.

27.Visser, W. (2014). CSR 2.0: Transforming corporate sustainability and responsibility. Springer. 